\title{
THE ROLE OF THE TEACHER AND EIGHT KEY COMPETENCE FOR LIFELONG LEARNING. CASE STUDY POLISH SCHOOL IN REZEKNE
}

\author{
Sylwia Szulc \\ Nicolaus Copernicus University in Torun, Poland
}

\begin{abstract}
In this article author present the impact of teacher competences on the role played in school. The object of the research is the role played by the teacher in the State Polish Grammar School in Rezekne. In order to compare theory with practice, empirical studies have been conducted in the two - month practice in State Polish Grammar School in Rezekne, which were completed within the practice of Erasmus+.

Keywords: school, teacher, teacher's role, competence, lifelong learning, cultural borderland.
\end{abstract}

\section{Introduction}

The aim of this paper is to show what kind of role teachers have at school at the example of a Polish school in Latvia, which is influenced by key competences acquired continuously in the process of learning throughout one's life. In order to confront theory with practice, empirical studies conducted in State Polish Grammar School in Rezekne which was part of the Erasmus+ program. The collected research data was based mostly on interviews. This article contains three research objectives, that is:

- Exploration (cognitive): determining whether and to what extent the competences of a teacher influence their role.

- Description (theory): Forming assumptions regarding roles that a teacher has.

- Explanation (practice): Emphasizing the multidimensionality of a teacher's roles in a peculiar environment where cultures overlap.

The aforementioned goals allow for establishing a broader perspective the role of a teacher, as well as the competences of teaching throughout their whole lives.

The theoretical issues of the topic are presented in the first part of the article. The following part contains the analysis of personal research. 
Sylwia Szulc. The Role of the Teacher and Eight Key Competence for Lifelong Learning. Case Study Polish School in Rezekne

\section{The social and professional role of a teacher and their tasks and functions performed at school}

\section{The social and professional role of a teacher}

The concept of a social role is connected with the position of an individual in a given society. The post indicates a person's position within the social, organisational or institutional sphere. D.J. Levinson notices that "a role is an aspect of physiological organization because it entails function, adaptation and process" (Szmatka, 1979: 31). Working in a specific organisation, e.g. a school, the role one plays in it is directly intertwined with the basics of its functionality. When we speak of a role, we really mean the function of an individual that they serve within an institution. It is also a process of adapting in a working position.

Social roles are the result of norms and directives that function within a society or a social group. Therefore, we can interpret them in different ways. First of all, as assigned warrants, that is to be able to adjust to a certain set of rules and general norms associated with a particular role. Second of all, as fulfilling the expectations of one's superiors, directors, but also society itself. A role fulfilled by a particular individual within an institution is a way of adjusting to an accepted norm. Certain pressures and rules are inhibitory or supportive to an individual.

According to R.Linton, a role "entails attitudes, values and behaviours assigned to individuals and groups of specific social status by the society" (Linton, 2000: 98). Each role performed by an individual is assigned to a particular template or scheme that the society is guided by when creating images, views or actions attributed to all members with social roles (Szmatka, 1979: 32).

Analysing different dimensions of fulfilling a role, it is imperative not to exclude the concept of a role dilemma, which assumes that each situation in a person's life can be linked to making decisions. Every decision is connected to suffering losses but also to personal gains. The source of a role dilemma may be the personality of an individual, which influences the forms of adaptation, but also the structure of the whole institution. Role dilemmas can thus be considered as all things unclear and ambiguous that stem from a certain role. As J. Szmatka says „each role entails norms, values, directives, etc. which are vaguely formulated, ambiguous, allow for different interpretations or even contradict other directives of a role" (Szmatka, 1979: 32).

Upon further analysis of the structure of fulfilling a role by an individual, it is important to notice the amenities of a role. Role amenities are "identified technical, ecological and cultural factors which influence certain norms that are part of orders and requirements so that they are exceptionally noticeable" (Szmatka 2007: 142). 
An individual's ability to adapt to doing a certain job and fulfilling a certain role depends on their personality and it is the sign of satisfying one's needs.

The professional role of a teacher is then understood as one of the social roles. K. Konarzewski indicates that social roles cover groups of expectations according to which an individual should behave and think. A person fulfilling a certain social role also has specific demands or requirements in accordance to other people from their environment (Konarzewski, 2002: 151). Students, headmasters, parents and the rest of the staff will be role partners for teachers. Doing a teacher's job is mostly depending on the society's views or the social context. These indicators create norms and standards which direct a teacher's way.

Teachers are responsible for both the upbringing and education of their pupils. They are people with thorough knowledge not only regarding a particular subject, but anything that goes beyond that, that is originality, creativity and composition. It is a teacher's job to provid professional help and solve problems and difficulties they may encounter on their career path. While fulfilling different kinds of roles, teachers have to become guardians who through communication are capable of approaching their pupil, parent or other guardian on a very individual level. It is an important task to motivate and cultivate moral values that can tremendously influence personalities of pupils (Bloch-Nabiałek, 2005: 76).

We can distinguish three functions that a teacher should perform. The didactic role, which is strictly connected with teaching the canon of knowledge, as well as harnessing all sorts of skills. The educational role, whose purpose is to shape moral attitudes, indicate general norms and rules that govern a particular society, as well as to develop pro-social skills. The role of a protector, that is to satisfy the basic needs of a pupil, both biologically and psychologically. It is also to care about their sense of security and respect (Bloch-Nabiałek, 2005: 76).

For the purpose of the following article, we to distinguish five roles related to the professional work of a teacher.

As a guide and interpreter, a teacher has to pave the way to understanding reality for their pupils. It is a person who help comprehend students environment, and through knowing what a society is aiming for and what it wants to maintain, they introduce generational transmission. It is important to notice that teachers introduce their disciples to the world of social culture. They reveal its past and future aims, as well as changes that transpire. They should explain the world to their pupils and show both the educational and everyday routes (Ferenz, 2009: 17).

As a reflective practitioner, it is a teacher's aim to reach deep thoughts that concern the objective (future), current action (present) and accomplished 
Sylwia Szulc. The Role of the Teacher and Eight Key Competence for Lifelong Learning. Case Study Polish School in Rezekne

tasks (evaluation of past results). When speaking of a reflective teacher, we mean their conscious practical action during which a critical analysis is applied, instead of spontaneous reactions described in behavioural psychology. As M.Czerepaniak puts it - "it is a person's attribute that allows them to understand a situation in which they act and depending on which they correct their own professional behaviour. It is a dynamic property which can be shaped and developed in the process of preparing for the job, reflected in deep reflection, as well as rational, critical judgement of individual elements and events that create an educational situation and their consequences regarding the development of people and social changes" (Ferenz, 2009: 19).

As a guardian-educator, a teacher takes direct care of students in a particular grade (Kupisiewicz, 2009: 195). They transfer messages and knowledge, shape the basics, competence, but also skills that students will use for the rest of their lives. It is important to emphasize that teachers in an education system not only provide theoretical knowledge but also values that accompany us on every step (Olczyk, 2003: 119).

As a transmitter and promoter of values, a teacher focuses on being a link between feelings and culture, which provides a clear message through cooperation. It is not simple transmission of knowledge regarding cultural heritage, but also a process of preparation to achieve innovation which is increasingly common in our world. It is about teach about creativeness and about a new outlook on the world which helps pupils to better understand both the present and the upcoming changes in the social world.

As a cultural animator of school life, a teacher helps individuals or groups to work on self-improvement. Animating may also transpire along with specific tasks or during problem solving. A teacher animator works primarily using integration and social participation (Matyjewicz, 2010: 46). They introduce their pupils to social life through integration with the educational environment, that is the family, school and peers. M. Kopczyńska mentions that animation actively supports the youth in problem solving and the difficulties which they face. It also teaches to reflect upon decisions regarding one's personal life through cooperation and self-control (Kopczyńska, 1996: 92).

\section{Teacher competences and set of competences vital in the process of lifelong learning}

Speaking of teachers, it is important not to omit the topic of competencies suitable for tasks they have to face. According to Stownik Języka Polskiego $P W N$, competencies can be defined in three ways. First, as a set of rights and capabilities thanks to which all individuals can deal with specific situations and make decisions. Second, this is knowledge, skills and experiences that an 
individual acquires. Third, this is the ability to react to stimuli (Doroszewski, http://sjp.pwn.pl/szukaj/kompetencje.html).

However, if we view competencies as a disposition, it is useful to quote Z. Ratajk who considers them to be indicators of being able to fulfil a role properly (Ratajek, 2001: 25). In this context, competencies favour problem solving and support an individual when analysing new situations. Another noteworthy definition belongs to R. White, according to whom "competencies are not only personal, motivational and consequently behavioural, but also social, because they give a certain character to our social surroundings" (White 1995:18).

M.Czerepaniak-Walczak indicates, that competencies "are special properties which are expressed while demonstrating on socially indicated standards the level of difficulty regarding adequate behaviour, the awareness of needs and consequences of that particular course of action as well as taking responsibility for it. It is a disposition achieved through constant studying, conscious to a person and capable of being observed and repeated by others. The structure of competence consists of two components: the ability to act accordingly and being aware of one's needs and repercussions of one's actions, as well as taking responsibility for the consequences" (Czerepaniak-Walczak, 1995: 135-137).

To summarize, competencies can be called an interdisciplinary term. We can find them meaning either in economic sciences, management or administration as an element of the human capital, a collection of its resources, which is particularly important in the labour market. Pedagogically speaking, we distinguish them as a set of attributes which are the effect of studying, the basis for upbringing and help for adequate behaviour. Competencies are then a collection of acquired knowledge, skills, attitudes and properties of one's personality (Whiddett \& Hollyforde, 2003: 15).

T. Lewowicki points to a pattern of competencies which are common for every teacher. We can distinguish personal competencies, which indicate a teachers sensitivity, their openness, their desire to talk, how much self-criticism they apply, self-realization, taking another person's right into consideration and being respectful and understanding. Psychological competencies, that is establishing a link between developmental psychology, diagnostics, negotiation, mediation, and also resistance to stressful situations. Pedagogical and methodological competencies, that is pedagogical knowledge and working methods, but also the correct way of reading the student's behaviour, understanding, looking for the causes of specific actions, as well as evaluating performed tasks, the content of the curriculum and work methodology (Sikorski, 2003: 55-56). 
Sylwia Szulc. The Role of the Teacher and Eight Key Competence for Lifelong Learning. Case Study Polish School in Rezekne

A number of definitions describing competencies inclines to consider their multidimensionality. While performing an analysis, it is imperative to take into consideration the reality of each and every teacher.

\section{Key competencies in the process of lifelong learning}

Both the European Parliament and the Council of Europe have expressed the necessity for lifelong learning. According to the recommendation of $18^{\text {th }}$ of December 2006 regarding competencies which are key in the process of lifelong learning, developing the offer of developing competencies is an extremely important strategy.

The following document determines up to eight key competencies and describes the most important knowledge, skills and attitudes associated with each of them. These key competencies include being able to communicate in one's native language, that is the ability to use one's native language in everyday communication, be it in speech or writing. It is the necessary vocabulary knowledge and a certain attitude towards one's nation. The ability to speak foreign languages, that is the ability to speak a different language that one's native one, as well as respect shown to different nationalities and knowledge that can be used in conversations. Both mathematical and basic scientific expertise, that is the ability to develop and use mathematical thinking in order to solve problems arising in everyday situations. This particular competence uses and goes back to knowledge and the basics which are incredibly helpful during tough situations. Competencies regarding information technology, that is skilled and critical usage of technologies of the information society. The ability to study, which is connected to the ability to learn things consequently and organise one's time in an efficient manner. Social and civil competencies, which includes all of the personal, interpersonal and intercultural. Initiative and entrepreneurship, that is the ability to implementation one's ideas. That includes creativity, innovation, but also the ability to take risks. The last of the competencies is cultural awareness and expression, which entails appreciation towards creative expression of ideas (Sikorski, 2003: 55-56).

\section{Analysis of the research data}

The area of empirical research, performed in a practical way in the following article, includes the role of a teacher and all the competencies necessary during the process of lifelong learning. The aforementioned issues were used during analysis of the collected research material. This analysis is to determine how effectively the key competencies acquired during the process of 
lifelong learning affect the way of performing the role of a teacher. The research is based on materials gathered during a two-month university internship in State Polish Grammar School in Rezekne in Latvia, as part of Erasmus+.

The following paper applies the model of qualitative research. Choice in this article is connected with the fact that "in qualitative research (...) it is possible to tackle subjects that go beyond that which is objective and measurable, which allows to research issues associated with judgement, values and experiences, that is all that is standalone" (Sikorski, 2003: 276). In order to answer the question what sort of role a teacher has in a Polish school in Latvia and what sort of influence it has on competence, it is essential to study the teacher, their working conditions, experience and reasons for pursuing that particular career. Qualitative research allowed me to look at certain cases of teachers working in a State Polish Grammar School in Rezekne. To analyse the gathered materials, used seven teachers narratives.

The conducted analysis of the study showed that competencies of each teacher influence the role they perform at school. You can distinguish a few roles: guardian, interpreter, reflective practitioner, educator, transmitter and promoter of values and cultural animator of school life. The assigned role depends on competencies that each teacher possesses, that allow them to perform a certain role according to social expectations. Through development of competencies, learning and gaining experiences, a teacher is increasingly better at their job, but also begins to perform other roles more efficiently, which stems from new circumstances.

The most important competences that can be detected from the collected research data is the ability to speak a foreign language. It is imperative for allows efficient functionality within every role in a multicultural environment.

The ability to learn allows a teacher extend their knowledge, acquire new skills, have them reflect upon certain things which may remain a long-lasting tendency. Studying helps in the process of self-evaluation, which favours the role of a reflective practitioner.

A guardian and interpreter depends on knowledge and experience. The teachers are open and friendly. The teachers are a companion, they show the way but do not impose it. They are a person who explains the world around them, for which they use competencies associated with knowledge, social and personal competencies, but also the ability to intrigue others.

The aforementioned research material does not only indicate the diversity of competencies that belong to the teachers of the State Polish Grammar School in Rezekne, but more importantly, it indicates the variety of roles performed by the teachers. A lot of them emphasize how important it is to explain reality, show the tendencies of social ways through transmission, aim to describe the world around us, which is especially emphasized by teachers consign from 
Poland to work in Latvia. The analysis indicates that teachers perform a very important role of a guide and interpreter. They become a companion on the way to gain knowledge and they participate in the process themselves.

Teachers also communicate certain values, extend the students' knowledge by speaking about Polish and Latvian culture, care for their pupils every day, for that is what is expected of them by parents. They care about safety which eventually turns them into guardian-educators.

The role of a cultural animator of school life is not to be omitted as well. A teacher, thanks to their entrepreneurship, initiative and ideas, becomes an animator. Teacher animate and encourages students to work, activates and cooperates with the rest of the staff which favours the creation of partnership between teachers, administration, management, but also parents.

It can be observed that competencies influence all the performed roles. While interpreting the aforementioned issues, it is essential to remember to take the social context into account, as well as the specifics of the environment.

\section{Conclusion}

This paper showed the influence of competencies of a teacher on the role performed in the State Polish Grammar School in Rezekne. The subject of this study was the social role assigned to teachers in the aforementioned school.

The paper had three aims. Exploration, which was to determine if and how strongly the competencies of each teacher influence their roles. This aim was achieved due to the gathered material, which, upon further analysis, proved that having adequate competencies in a specific role is of utmost importance. In a situation where a teacher does not possess the appropriate competencies, they still fulfil the assigned role because it is associated with the expectations imposed on them. Therefore, one can theorize that a certain range of competencies in a specific role allows for adequate performance, while the lack of those competencies results in being unable to meet the expectations associated with that role.

Description, that is formulating assumptions regarding a teacher's performance, was reflected in the analysis of the conducted research, which is based on the basic theoretical claims regarding a teacher's role. Those claims are linked to the fact that each educator present in the school represents the role of a guardian, interpreter, reflective practitioner, educator, transmitter and promoter of values and cultural animator of school life. To be able to fulfil them properly is however connected with the competencies of a teacher.

Explanation, that is drawing attention the multidimensionality of performed roles in a peculiar environment where culture overlap. It is especially 
connected with working experience, social pressure regarding certain teachers and their competencies. Research data proves that the same roles performed by different teachers, differ from one another.

Analysing the research data proves how important it is for performing a social function to develop one's competencies, which influence a certain role in a direct way. Teachers numerously show that thanks to teaching using practical work, using experience and even through a conversation with another educator, the pupils' future behaviour is formed.

Competencies of each teacher are not creators of social roles performed by educators. The more they are developed, the greater influence they have over feeling comfortable in a role, which can be particularly noticed in people with greater working experience.

On a number of occasions, teacher look back to their own experiences, thanks to which they changed their behaviour using reflective thinking. This kind of behaviour also proves that competencies are developed through practice and reflection.

The paper is going to prove an inspiration and help to those interested in the topic of roles and competencies of a teacher in an environment where cultures overlap. This study of the subject presents the issue in the most understandable, factual and objective way, but also shows conclusions which may inspire further pedagogical actions.

\section{References}

Bloch-Nabiałek, A. (2005). Nowe spojrzenie na rolę, zadania oraz osobowość opiekuna i wychowawcy. In: T. Zacharuk Pedagog jednej czy wielu dróg? Część 1. Pedagog w teorii. Poland: Siedlce.

Czerepaniak-Walczak, M. (1995). Między dostosowaniem a zmianq. Elementy emancypacyjnej teorii edukacji. Poland: Szczecin.

Czykwin, E. (1995). Samoświadomość nauczyciela Poland: Białystok.

Doroszewski, W. (2016). Stownik jęzka polskiego http://sjp.pwn.pl/szukaj/kompetencje.html (11.04.2016).

Ferenz, K. (2009). Role nauczyciela we wprowadzeniu młodego pokolenia w życie społeczne i kulturalne. In: K. Ferenz, S. Walasek Role wspótczesnego nauczyciela w zmieniajacej się rzeczywistości społecznej. Poland: Wrocław.

Konarzewski, K. (2002). Nauczyciel. In: K. Konarzewski Sztuka nauczania. Szkoła. Poland:Warszawa.

Kopczyńska, M. (1996) Normalizacja: między biernym przystosowaniem i zależnością a aktywnym uczestnictwem i autonomią - o jednym z dylematów pedagoga - animatora. In: A. Przecławska Pedagogika społeczna. Kregi poszukiwań. Poland: Warszawa.

Kupisiewicz, C., \& Kupisiewicz M. (2009). Stownik pedagogiczny. Poland: Warszawa.

Levinson, D.J. (1979). Rola, osobliwość i struktura społeczna. In: J. Szmatka Elementy mikrosocjologii. Wybór tekstów, Tom I. Poland: Kraków. 
Sylwia Szulc. The Role of the Teacher and Eight Key Competence for Lifelong Learning. Case Study Polish School in Rezekne

Linton, R. (2000) Kulturowe podstawy osobowości, posponed A. Jasińska-Kania. Poland: Warszawa.

Matyjewicz, M. (2010) Animacja kulturalna. W poszukiwaniu obszarów wspótczesnego wychowania. Poland: Olsztyn.

Olczyk, A. (2003). Nauczyciel na miarę XXI w. In: D. Waloszek Pytania o edukację. Poland: Zielona Góra.

Ratajek, Z. (2001). Profesjonalizm współczesnego nauczyciela a możliwości zmian jego kształcenia w systemie akademickim. In: E. Sałata Kompetencje zawodowe nauczycieli a problemy reformy edukacyjnej. Poland: Radom.

Sikorski, M. (2008). Rozważania o kwalifikacjach pedagogicznych nauczyciela. In: K. Żegnałka Kompetencje wspótczesnego nauczyciela. Poland: Warszawa.

Szmatka, J. (2007). Małe struktury spoteczne. Poland: Warszawa.

Whiddett, S., \& Hollyforde S. (2003). Modele kompetencyjne $w$ zarzadzaniu zasobami ludzkimi. Poland: Kraków. 